\title{
The unity of Luke-Acts
}

\author{
J Verheyden' \\ Katholieke Universiteit Leuven \\ Research Fellow of Andries $G$ van Aarde \\ Professor of New Testament, University of Pretoria
}

\begin{abstract}
The article contains a summary of contributions delivered at he $47^{\text {th }}$ Colloquium Biblicum Lovaniense (1998) held at the Catholic University, Leuven on the subject: "The unity of Luke-Acts". The opening address was delivered by $J$ Verheyden (Leuven) on "The Unity of Luke and Acts: What are we up to?". The contributors were: $J$ Kremer (Vienna) - "Die dreifache Wiedergabe des Damaskuserlebnis Pauli in der Apostelgeschichte: Eine Hilfe für das rechte Verständnis der lukanischen Osterevangelien"; D Marguerat (Lausanne) "Jusqu' où faut-il parler d'une "unité". Luc-Actes? Continuité et ruptures dans l'avre de Luc"; J Delobel (Leuven) - "The text of Luke-Acts: A confrontation of recent theories"; $R$ $L$ Brawley (Chicago) - "Abrahamic covenant traditions and the characterization of God in Luke-Acts"; F W Horn (Mainz) - "Die Haltung des Lukas zum römischen Staat im Evangelium und in der Apostelgeschichte"; $J$ A Fitzmyer (Washington) - "The role of the Spirit in Luke-Acts"; M Rese (Münster) - "The Jews in Luke-Acts: Some second thoughts"; J Taylor (Jerusalem) - "La fraction du pain en Luc-Actes"; W Radl (Augsburg) - "Die Beziehungen der Vorgeschichte zur Apostelgeschichte, dargestellt an Lk 2:22-39; F Neirynck (Leuven) - "Luke 4:16-30 and the unity of Luke-Acts"; C M Tuckett (Oxford) - "The Christology of Luke-Acts"; O Mainville (Montréal) - "Le messianisme de Jésus: Le rapport announce/accomplissement entre Lc 1,35 a Ac 2,33"; A Lindemann (Bethel-Bielefeld) - "Form und Funktion von Reden und Wundererzahlungen im Lukasevangelium und in der Apostelgeschichte", A Denaux - The theme of divine visits and human (in)hospitability in Luke-Acts and its Old Testament and Graeco-Roman antecedents.
\end{abstract}

\section{INTRODUCTION}

The 47th session of the Colloguium Biblicum Lovaniense, held at the Leuven Faculty of Theology, July 29-31, 1998, was devoted to the study of "The unity Luke-Acts". About

\footnotetext{
' Dr Jos Verheyden visited the University of Pretoria as research fellow of Prof Dr Andries G van Aarde, July-August 1999.
} 
150 participants attended the meeting. On the programme were eleven main papers, four seminars, and twenty-seven offered papers.

Thirty years ago, in 1968, the topic of the 19th Journées Bibliques (with F Neirynck as its president) was "L'évangile de Luc", the first in a series on each of the canonical gospels. Matthew followed in 1970, Mark in 1971, and John in 1975. The next New Testament session in 1977 (chaired by J Kremer) dealt with "Les Actes des Apôtres". Several contributors at the conferences of 1968 and 1977 discussed passages and themes of the Gospel of Luke or the Book of Acts with an eye on the other volume. But the specific and "unique phenomenon" (Van Unnik) that a Gospel writer composed his account as part of a larger work had not yet been dealt with as a separate topic at the Colloquium. So, this year's session, while taking us back in a certain sense into the history of the Journées Bibliques, also added something new to it. In the following I will briefly present the content of the main lectures (in the order of the programme) and of the seminars.

My opening address (The unity of Luke and Acts: What are we up to?) introduces the topic and surveys the research regarding different aspects of the unity of Luke's work. There may be an almost complete consensus on the view that Lk-Acts were written by the same author, but scholars otherwise use various models to designate the relationship between both volumes. While some refer to "Acts as the intended sequel to the Gospel" (I $\mathrm{H}$ Marshall), others will regard Acts as the continuation of a work that is already complete in itself (M C Parsons - R I Pervo). In my survey I pay special attention to the works of $H$ $\mathrm{J}$ Cadbury and $\mathrm{H}$ Conzelmann. Cadbury's famous definition of $\mathbf{L k}$-Acts as "a single continuous work" showed the way for studying Luke's double work as a narrative unity with a common purpose. His influence on subsequent research is illustrated with the discussion about the extent of the prologue in $\mathrm{Lk} 1,1-4$ and possible indications in the Gospel that Luke was already looking forward to Acts. With Conzelmann, Luke became a theologian in his own right. His emphasis on the theological significance of Luke's work as a whole opened the discussion on what constitutes its distinctive theology and how to describe it. Is Luke's theology ruled by one central motive as some have thought? Or is it built according to one basic (theological) model, for example the apology or the model of announcement and fulfilment? This second model has proven to be very attractive in understanding the connexion between Luke and Acts and between Luke's work and Jewish tradition. Or should one look for coherency in Luke's thinking within a particular area (his 
christology or his pneumatology or ecclesiology)? The study of the genre and of the narrative unity of Luke's work and his artistry as a redactor and author bring in other aspects of the discussion. Luke masters a wide variety of narrative techniques that show up in both volumes of his work, some of which (such as his fondness for parallel stories) are fundamental for reading $\mathrm{Lk}$-Acts as one continuous composition.

J KREMER (Wien), in a lecture entitled Die dreifache Wiedergabe des Damaskuserlebnis Pauli in der Apostelgeschichte: Eine Hilfe für das rechte Verständnis der lukanischen Osterevangelien, analyzes the threefold account of Paul's past as a persecutor and the decisive event of his conversion on the way to Damascus as a means towards a correct understanding of the encounters of the disciples with the Risen Lord in Luke 24. Kremer proceeds in four steps, offering first a synchronic and then a diachronic reading of the stories in Acts $(9,3-22 ; 22,6-22 ; 26,12-19)$, a comparison with Luke 24, and finally formulating some conclusions about the fictional character, and the implications for our interpretation, of Luke's accounts. Luke and the author of the tradition of Saul's conversion are not interested in providing a historically reliable report of this event; they rather want to emphasize the divine initiative in the expansion of the early mission and to illustrate how God turns the former persecutor into one of his most important agents. The comparison with Luke 24 shows that Luke relied on earlier traditions which can (in 24, 1$12 \mathrm{Lk}$ depends on Mk 16, 1-8) or cannot be identified (24, 13-35.36-53 are thoroughly reworked by Luke), but which he has made his own. As an important characteristic of Luke's redaction Kremer points to the "novelistic" presentation and to his reshaping of the narratives, $\mathrm{e} g$ by turning a conversion story into a call story with a vision (Acts 22,17-22).

D MARGUERAT (Lausanne) explores the limits of the hypothesis of the unity of Luke's work: Jusqu'où faut-il parler d'une "unité" Luc-Actes? Continuité et ruptures dans l'ceuvre de Luc. Marguerat does not deny the literary and theological unity of LukeActs, but this unity is "a heuristic proposition" which is to be verified on the text and is realized in the act of reading. The reader must discover the signs the author has put in his text in order that his work should be read as a unity. In an initial section Marguerat first sums up some remarkable discontinuities (e g, the change from a kerygma that is centered on the Kingdom in Luke to one that is basically christological in Acts). He then formulates the principles behind his own reading for which he is influenced by the work of $G$ Genette. Acts is a rereading (relecture) of the Gospel. It is not a commentary of Luke, nor a repe- 
tition, but a continuation of the account in the Gospel which brings about a postponed rereading of this latter (une relecture en différe). Marguerat analyzes three models of relecture, each of which contains specific text markers. The first one, which he calls "a rereading by progressive elucidation", comprises such techniques as elliptic prolepsis, relocation of information from the Gospel to Acts, or the narrative chains Luke installs between different stories. The second one, relecture par modélisation in Marguerat's terminology, is perhaps better known as the old rhetorical technique of synkrisis. Luke models a story in Acts on a similar one from the Gospel and creates a comparison between the deeds (not the words) of his main characters, Jesus and Peter, Jesus and Paul, or Peter and Paul. This parallelism is guided by the story of Jesus, but there always remains a difference between the initial act of Jesus and the imitation of it by the apostles. A more complex relation is found in the third model, the rereading by relocation, which focuses on themes for which there seems to exist a tension between the Gospel and Acts (e g regarding the Law or the Christian attitude towards wealth and property). Apparently Luke did not want to do away with these tensions. Marguerat distinguishes between Luke the theologian and Luke the historian, and emphasizes the function of both themes in establishing the Christian identity as Luke saw it.

J DeLOBEL (Leuven) surveys recent work on the text of Luke-Acts (The text of Luke-Acts: A confrontation of recent theories). The discussion on the relationship between the Alexandrian and the Western text in Luke-Acts, which seemed a foregone issue in Lukan studies, was reopened in the mid eighties. Taking as his starting point the survey of B Aland (ETL, 1986), Delobel presents the works of É Delebecque (1980-1986), M-É Boismard and A Lamouille (1984), W A Strange (1992), C-B Amphoux (several contributions from 1986 on with special consideration for the Codex Bezae), J Rius-Camps (esp the series of articles on the Western recension in Acts), and P Taverdon (1997) who continues in the line of Boismard. In a last section he formulates some observations on this revival of the interest in the Western text. One should realize, first, that those who are opposed to the consensus opinion do not constitute a homogeneous group. And second, a critique of the attempts at reassessing the value of the Westem text should focus on the qualities of the methods that are proposed. Delobel makes nine observations in this regard which do not all apply to each and everyone of the proponents of the Western text. He is sceptical about the ease with which some authors go from the level of "tradition" to that of 
"written sources" that are no longer available to us. At the same time these authors have no problem with accepting the traditional ascription of Luke-Acts to a companion of Paul. He further points out some of the risks and difficulties in using arguments based on the occurrence of doublets (do they always have to go back to different traditions?) or of "Lucanisms", and warns for too optimistic views on the possibility of reconstructing the Western text on the basis of Codex Bezae or other evidence. An important difficulty remains the lack of direct evidence from the second century, which is responsible for the widely diverging conclusions that are proposed regarding the date of the Western recension and of its nature. As a general observation, several of the attempts suffer from a lack of balanced text-critical method giving too much importance to internal criticism (e g, BoismardLamouille).

R L BRAWLEY (Chicago), in his paper on Abrahamic covenant traditions and the characterization of God in Luke-Acts, offers a reading of all the passages that refer to Abraham as a key towards a (partial) understanding of Luke's characterization of God. From the outset it is clear that the references to the Abrahamic covenant traditions stand along those to other OT figures as Moses and David. Thus Mary's interpretation in 1,37 of Gabriel's announcement, which echoes Davidic traditions (1, 32-33), leads the reader beyond David to the scene in Genesis 18, 14 that proclaims the power of God to keep his promises. Zechariah's interpretation, on the other hand, is a synthesis of the two previous ones, though in such a way that God's promises to David are seen as the fulfilment of those that were given to Abraham. Brawley then discusses the other Abraham passages which together offer a double characterization of God as the One who keeps promises and whose blessings are not bound to laws on religious praxis but include all the families of the earth (cf $L k 3,8$, where the negative qualification of the appeal to Abrahamic descent is balanced by the positive moment of revaluation by referring to the criterion of repentance; 13, 10-17, with the expression "daughter of Abraham" that is reminiscent of 4 Maccabees 15, 28 and the quotation of Genesis 22, 18 in Acts 3, 25; 13, 28-29, and also 16, 19-31 and 19,1-10, all three again characterize God as the One who blesses all people). Abraham plays a prominent role in the speech of Stephen who recalls the old promise about inheriting the land $(7,3-5)$ which is followed by a reference in 7, 16-17 to the fulfilment of God's promise to Abraham. Finally, the reference to Abraham in Paul's speech at Antioch is seen as in some sort summarizing God's promises to God's people. Moreover, like Stephen, Paul 
synthesizes the covenant traditions about Abraham and David, subsuming the latter under the former. This is indeed Luke's way of understanding the significance of the promises originally made to Abraham. God has repeated them throughout history to Moses and David, and even if the Davidic and Mosaic covenants may have failed in some respect, it is the Abrahamic covenant that remains the touching stone.

Die Haltung des Lukas zum römischen Staat im Evangelium und in der Apostelgeschichte is the title of the lecture by F W Horn (Mainz), who takes as his starting point the often formulates conclusion that for Luke it were the Jews who were opposed to Jesus and his followers, against the will of the Roman authorities who rather protected the Christians and saw no harm in their mission. In three parts Horn offers an exegetical study of the trial scenes of Jesus and Paul, a survey of recent contributions on the topic, and a proposal regarding Luke's intended audience on the basis of his dealing with the Herodian dynasty. Luke clearly puts the blame for the condemnation of Jesus and of Paul with the Jewish religious authorities. Pilate and his ally Herod Antipas in Luke, and the Roman military government in Acts, are not convinced of their guilt and, in the case of Paul, are rather more concerned about his safety (Acts 23, 23). In the literature Luke's positive attitude towards the civil authorities is generally recognized, whatever one thinks that may have been the reason behind this apology. Herod Antipas and the other members of the dynasty are presented by Luke as reliable allies of Rome. They are his witnesses before his Roman audience that Christianity is not to be feared as a politically threatening movement. Those few passages that offer a different picture ( $\operatorname{Lk~13,31;23,11;~Acts~4,~27-28)~and~put~Herod~}$ and Pilate on the side of the opponents of Jesus, testify to what may have been historically the more probable situation and to the degree of Luke's efforts to discharge the Roman authorities and their allies of the accusation that they had any part in the death of Jesus.

J A FITZMYER (Washington) addresses another important topic in Lukan studies. His paper on The role of the Spirit in Luke-Acts comprises three sections. In the first and second one he looks for the sources of Luke's references of the Spirit in Greco-Roman literature and in the LXX. In the third one he goes through the relevant passages in LukeActs to present a general description of Luke's understanding of the role of the Spirit in the life of Jesus and of the early Church. Fitzmyer is sceptical of a possible Hellenistic influence. Though the concept of "inspiration" is well attested in contemporary Greek lite- 
rature, the specific interpretation of $\pi v \varepsilon v \hat{\mu} \alpha$ that is found in the texts of the New Testament is absent from it. Luke depends on the LXX both for the vocabulary that he uses (e g,

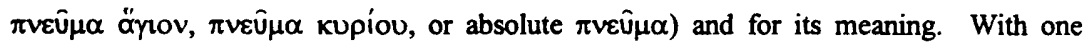
exception (the "Spirit" of Jesus in Acts 16,7), $\pi v \varepsilon u \mu \alpha$ (ärov or kupiov) refers to the Spirit of God and expresses God's presence to God's people. This presence is especially experienced and mentioned at the beginning of each period in Luke's conception of salvation history. It is the Spirit of God who inaugurates a next development in that history. The Spirit is with Mary at the conception ( $L k 1,35)$, with Jesus at his baptism ( $L k ~ 3,22)$ and his temptation by Satan $(4,1.14)$, and with the apostles at the ascension (Acts 1, 9-11) and at the beginning of their ministry $(2,4.36)$. This emphasis on the presence of the Spirit at the beginning of a new era in salvation history is in contrast with the Spirit's absence later on, in the ministry of Jesus (the Spirit plays no role in Jesus' miracles) or of his disciples (no mention of the Spirit in Acts 17-18 or 22-27). On the other hand the Spirit of God is mentioned again at certain crucial events in the history of the Church, as in Acts 15 or in the account of Saul's conversion in Acts 9. In Acts the Spirit also becomes personified at times. In some passages, as in Acts 5, 3-4, this personification adds an element of dramatisation. In the Old Testament or non-personified use, the Spirit is spoken of as a gift, as something that falls or comes upon people who so become filled with or full of the Spirit. This use is consistent in the Gospel and in Acts and marks both volumes which are otherwise bound together by such references to the Spirit as the quotations from Isaiah 61, 1-2 and Joel 3, 1-2 in Luke 4, 18-19 and Acts 2, 17-21. The reference to the Spirit in Jesus' and in Peter's opening discourse makes it clear to the reader that the Spirit that was given to Jesus at the beginning of his ministry is identical with the one that will be given later on to the whole of the community, indeed that the disciples in Acts 2 receive the Spirit of Jesus.

M RESE (Münster) deals with the crucial issue of the role of the Jews as the audience and opponents of Jesus and as addressees and characters of Luke's account (The Jews in Luke-Acts: Some second thoughts). Rese's "first" thoughts are found in an article he contributed to the FS G Schneider in 1991. They are briefly summarised in the first part of his lecture and supplemented with a survey of the more recent literature. As before, current discussion centers around the question whether or not Luke, through the mouth of Paul, has "written off" the Jews (Haenchen). Rese is critical of J Jervell's positive inter- 
pretation of oi Ioudaior in the Gospel and Acts. Two aspects of the discussion that have received quite some attention in recent years are the identification of the God-fearers as Jews and the alleged Jewish origin of the author of Luke-Acts. Though he shows sympathy for some of the attempts proposed in this regard (e g, by J B Tyson and D L Tiede), Rese also draws attention to the methodological difficulty of interpreting a text on the basis of presuppositions about the historical situation of Luke and his audience. In the second part of his lecture, Rese points out the difference there exists between the mention of oi

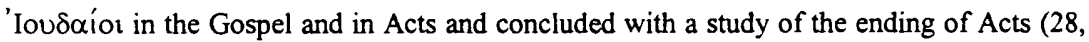
17-31). From the significant difference in attestations of the plural in Luke (only $5 x$ ) and Acts $(79 \mathrm{x})$, he draws the double conclusion that Luke, on the one hand, emphatically distinguished between the literary genre of the Gospel and of Acts (a negative attitude to the Jews was understandable in an account of the growth of the Church out of Judaism, but less so in the Gospel) but, on the other hand, since Luke-Acts were intended as a unity, also could afford it to leave out the criticism from his first volume because he had planned to integrate it in the second one. As to Acts 28, 17-31, Rese is sceptical of attempts to read the whole of Luke-Acts from its closing scene and to read it as an expression of hope that for Luke the fate of the Jews is not sealed. By way of conclusion he again points out (as he did already in 1991) that there remains a contrast between Paul's dealing with this topic in Acts 28, 17-31 and in Rom 9-11.

J TAYLOR (Jerusalem), in his paper on La fraction du pain en Luc-Actes, argues that the custom among early Christians to break the bread (while nothing is said of the wine) is certainly not in all instances to be linked with the celebration of the eucharist. His reasoning is based on the evidence from the New Testament (e g, Acts 20,7.11) and on a detailed analysis of chapters 9 and 10 of the Didache which show that the rite could have different connotations. Among these is the interpretation of the breaking of the bread as symbolising the dispersion of the faithful. It was probably followed by the positive act of reassembling the "pieces", a moment that is also explicitly mentioned in the feeding narratives and for which Taylor finds further evidence in such passages as Mark 13, 19-20 and John 10, 12 $16 ; 11,50 ; 17,21-23$, but also in Luke's version of the Last Supper. Defending the shorter reading at Luke 22, 19-20, Taylor speculates about the possibility that the rite of breaking the bread could be a fragment of that same pattern of negation (here the death of Jesus) and 
future restauration (in the Kingdom of God). This would bring Luke's version very close to Paul's interpretation in 1 Corinthians 11, 23-26 and to Didache 9, 4. In the Emmaus story the mention of the breaking of the bread by Jesus in Luke 24, 35 is to be understood in the same way as referring to the death of Jesus and the hope of his resurrection (again, on the assumption that the act was followed by one of assembling). Thus, the rite, as part of a double movement, could take different meanings, symbolising as well the death and resurrection of Jesus as the dispersion and future gathering of God's people.

In his lecture on Die Beziehungen der Vorgeschichte zur Apostelgeschichte, dargestellt an $L k 2,22-39$, W Radl (Augsburg) examines how the Infancy narrative, as the "prologue" to Luke's Gospel, and more specifically the narrative of the presentation of Jesus in the Temple with the prophecies by Simeon and Anna, also is related to Acts. In a first section Radl summarizes the results of his analysis of 2, 22-39 as these are found in his recent monograph (Der Ursprung Jesu: Traditionsgeschichtliche Untersuchungen zu Lukas 1-2, 1996). He draws attention to the contrast in genre and content between the optimistic and universalistic perspective of the poetic prophecy in vv 29-32, which he attributes to Luke's redaction, and the continuation in $v 34$, which sounds more threatening and deals exclusively with the hopes and fate of Israel. He then compares some of the core elements of the Simeon story with similar stories in Acts. The figure of the pious Jew who abides by the Law, goes up to the Temple, and lives a life of prayer, fasting, and justice, in the expectation that the fulfilment of Israel's hope is near, is met time and again in Acts. Just as the Spirit reveals to Simeon that he will "see" the Messiah (Lk 2, 25-26), so is Comelius informed by an angel that he should invite Peter to his house to receive his preaching (Acts 10,22 ), and Paul himself reports about the vision of the Lord he was privileged to see in the Temple $(22,18)$. In his double prophecy Simeon calls Jesus tó $\sigma \omega \tau$ rńprov but also the

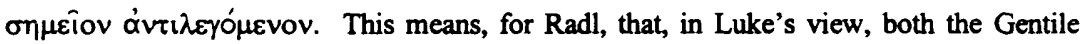
mission and the rejection of the kerygma by the Jews were planned by God, and consequently that the former is not merely the result of the latter. But Simeon also speaks of the glory of Israel $(\mathrm{Lk} 2,32)$ and of the rising of many in Israel $(2,34)$. The tension that is felt in these prophecies is found also in Acts where it is said, on the one hand, that many in Jerusalem were converted, and, on the other, that the Jews stubbornly went on rejecting Paul's preaching. It is inherent to Luke's story and reflects, according to Radl, the double 
perspective from which Luke was writing: as an historian, he looks back at how the separation of the synagogue gradually became irreversible; as a theologian, he interprets the rejection of the Christian mission and the re-establishment of the house of Israel as a house for Jews and Gentiles alike as the realization of God's plan that was foreseen by one of God's prophets.

F NEIRYNCK (Leuven) examines the parallels with and allusions to Jesus' opening discourse in the Book of Acts (Luke 4, 16-30 and the Unity Luke-Acts) observing that "references to Luke 4, 16-30 are rarely noted" in the current literature on Acts. Similarities with Luke 4, 16-30 can be found in Paul's synagogue preaching in Damascus (Acts 9, 19b25), and particularly in the important speech of Paul in Antioch (13, 14-52). A special case is the reference to Jesus' anointment with the Spirit in 10, 38 (cf Lk 4, 18) Neirynck concludes his survey with a note on the recent discussion on N $\alpha \zeta \alpha \rho \alpha$ in Luke 4, 16 which is now reclaimed for $\mathrm{Q}$ by the editors of the Documenta $\mathrm{Q}$ Database. Paul's inaugural preaching immediately after his conversion already follows the plan of his later missionary work and comes to the same negative results that are so frequently mentioned elsewhere in Acts (the public preaching in the synagogue meets with no success and ends in threats and attempts at the life of the missionary). This presentation is clearly influenced by the scene in Luke 4, 16-30 and differs from Paul's own accounts of his mission in Galatians 1, 17 and 2 Corinthians 11, 32-33 in which he does not yet speak of the hostility he met from the Jews. The introduction to the speech in Antioch in 13, 14-52 (vv 14-16a) can be compared with Luke 4. 16 with regard to the vocabulary (going to the synagogue on Sabbath), but Neirynck is sceptical of readings that make use of the passage in Acts to interpret the

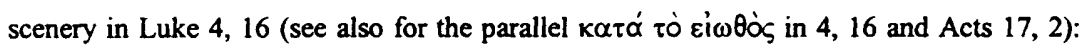
one cannot simply transpose the description of Acts 17, 2 and 13, 15 to Lk 4,16 and suppose that Jesus had made it his habit of teaching in the synagogue on the Sabbath or that he was invited by the synagogue officials to take the floor as Paul is in 13,15 . The reaction of the Jews (and the proselytes) in 13,43 and 13,45 is again comparable with that of Jesus' audience in Luke 4: initial openness to the preaching ends in hostility. The distinction that is often made with reference to $v 43$, indicating that Paul succeeded in converting at least some members of his audience, may be not correct since áko $0 u \theta^{\prime} \omega$ is used here with a literal meaning. The final result of Paul's preaching is outright rejection on the part of the 
Jews (Neirynck sees no reason for attenuating in one way or another the wording of $v 45$ ) and the firm announcement by Paul of his turning to the Gentiles. Here again the similarity with Luke 4 can be stressed, provided one is ready to read an allusion to the Gentile mission in the references to Elijah and Elisha in vv 25-27. The references in 10,38 to Jesus being anointed by God with the Spirit and to Isaiah 61, 1 (cf Lk 4, 18-19) constitute another kind of parallel with the opening discourse of Jesus: it has nothing to do with the way the ministry of Paul is compared with that of Jesus, but it looks rather as an explicit reference to the Gospel passage. In the discussion on the origin of the "mixed" Isaiah quotation in Luke 4, 18-19 examples from Acts $(1,20 ; 3,22-23)$ may be quoted in favour of its Lukan character. Similarly, Neirynck remains critical of the argument for assigning 4, 18-19 to a pre-Lukan source because Jesus' power to perform miracles is there ascribed to the Spirit, while in Acts 10,38 this is regarded as the work of God. The explicit mention of ó $\theta \varepsilon \dot{c}$ 甬v $\mu \varepsilon \tau$ ' $\alpha \hat{\mathrm{U} \tau o \hat{U}}$ at the end of Acts 10,38 does not rule out the emphasis on the effective presence of the Spirit in Jesus that is found in v 38a.

Seminars were conducted by A Denaux (Dutch), C M Tuckett (English), O Mainville (French), and A Lindemann (German); they were chaired by B J Koet, D P Moessner, M Dumais, and D-A Koch. A Denaux (Leuven) discusses The theme of divine visits and human (in)hospitality in Luke-Acts and its Old Testament and Graeco-Roman antecedents. He distinguishes four areas of application of the motive of hospitality. A first area is that of ethics, as in the parables of Luke 14, 7-14 and 14, 15-24 where Luke reflects on the essence of hospitality and presents a view that differs from the current appreciation of hostguest relations in his time. Luke also uses the motive in a christological sense to describe Jesus' earthly life and ministry in terms of a divine visit, of God who comes to earth and is received (or not) in an appropriate way as an honoured guest (see esp Lk 9, 51-19, 44). The missionary work of the disciples, as it is modeled after Jesus' ministry, forms a third field, in which hospitality is interpreted in an ecclesiological perspective (in the missionary discourses in Luke 9-10 and often in Acts in the stories about Paul). And finally hospitality is used by Luke as a metaphor for the Kingdom of God (the eschatological banquet of 13, 22 30). In the second part of his paper Denaux further develops the christological or theological use of the motive arguing that Luke has taken over this theme of divine visit from Graeco-Roman literature (and also from the LXX). Among the former one should mention 
above all the story of Philemon and Baucis in Ovid's Metamorphoses; the clearest example in the Old Testament is undoubtedly the story of God's visit to Abraham in Genesis 18. The motive occurs in Luke in the very beginning of the Gospel (the angelophanies in 1, 525 and 1, 26-38) and again in the Emmaus story. In the three passages Denaux discovers the same pattern. A verb that is frequently used by Luke in this connexion is

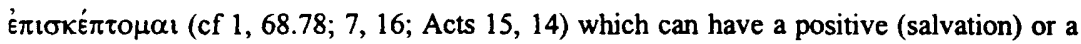
negative connotation (punishment) and can be translated as "visit" or as "look favorably upon" (in an eschatological perspective).

C M TUCKETT (Oxford) deals with The christology of Luke-Acts. Luke's christology is a central topic in current Lukan scholarship. By way of introduction Tuckett first reflects on what is meant by "the christology of Luke-Acts" (the christology of its historical as distinguished from that of its implied author). He then goes on to discuss the methodological problems involved in studying New Testament christology in general, in particular in determining the meaning and the relevance, besides other evidence, of the christological titles that were used by the early Christians to express their understanding of Jesus (and which remain the basis for any discussion). As a next step one has to ask whether Luke's writings contain evidence of a single christology or whether it would be more appropriate to speak of several Lukan christologies. It is striking, according to Tuckett, that Luke in his Gospel has taken over some of the identifications from his sources (Jesus as Son of Man, Jesus as a prophet of Wisdom or as a prophet like Moses) which he does not use again in other instances or in his other volume. Tuckett finds a basis for consensus in the conclusion that Luke's christology is before all a christology of the Exalted One, even though it remains debated what are the implications of such a statement. Several recent studies defend the view that Luke's writings represent a unified "high" christology of Jesus, as the Messiah-Servant (D L Bock), as the divine Lord of the Spirit equal to God (D Buckwalter), or as the Davidic Messiah-Prophet (M L Strauss). None of these attempts have convinced Tuckett. A major argument is the observation that Luke seems to have abandoned his christology at certain points in his narrative. For example, the representation of Jesus as Lord does not play a role in the christological debates in Acts about the Gentile mission or the identity of Jesus (who is called the Christ, not the Lord, in Acts 17, 3; 18, 5.28). This qualification, Jesus as the Christ, is the only one, according to Tuckett, that could possibly 
fit a description of Luke's christology as a consistent whole. But perhaps more typical is the variety of titles which are found in Luke-Acts and which lead to the conclusion that Luke is closely following his sources.

O MAINVILLE (Montréal) further develops the topic of her 1991 monograph in a paper on Le messianisme de Jésus: Le rapport annoncelaccomplissement entre Lc 1,35 et Ac 2,33. Her thesis is that these two passages complement each other, the first one identifying the nature of Jesus' messianism as a "pneumatic messianism", while the second brings the confirmation of this promise. Against more common positions which place this event at Jesus' baptism or at his birth or conception, Mainville holds that Peter's speech at Pentecost is the demonstration that for Luke Jesus really was made the Messiah only at the resurrection. The quotation from Isaiah 42, 1 in Luke 3, 22 favours a prophetic understanding of God's words (contrary to the variant reading of the Western text which quotes here from Ps 2, 7). In Acts 2, 22-36 Peter places the decisive moment of Jesus' investiture as the Messiah at the resurrection and of this the disciples bear witness $(2,32-33)$. Corroboration of this view is found in the speech of Paul at Antioch who follows the same pattern of argumentation (the witnesses in 13, 33; use of the testimony of David in 13,3637 as in 2, 29-31.34). As Messiah Jesus is identified with the Spirit who will rule and direct the missionary life of the community. This qualification of Jesus' Messiahship is expressed in Acts 2, 17-21 in the quotation of Joel 3, 1-5 and in Acts 2, 33 with its implicit reference to Isaiah 11, 1-2. What was accomplished at the end of the Gospel and made known to the world by Peter at the beginning of Acts, was already announced at the very beginning of Luke's Gospel in the words the angel Gabriel spoke to Mary about the promise of the Spirit and of the birth of a holy child $(1,35)$. Mainville argues that the reply of the angel in $v 35$ does not provide the answer to the question that bothers Mary in v 34. In other words, $v 35$ does not say that it is the Spirit who will engender Jesus. The role of the Spirit is to give "holiness" to the child that will be born (cf "therefore ..." in v 35a). The angel already looks forth at what will happen in the Gospel. Mainville concludes by pointing out that such a pattern is consistent with Luke's theology and with his composition.

A LINDEMANN (Bethel-Bielefeld) takes as his topic the parallelism between some of the speeches and between some of the miracle stories in Luke's writings. In his discussion 
paper Zu Form und Funktion von Reden und Wundererzählungen im Lukasevangelium und in der Apostelgeschichte, he first compares Jesus' preaching in Nazareth (Lk 4, 16-30) with Peter's speech at Jerusalem (Acts 2, 14-42) and continues with a comparative analysis of the story of the healing of a paralytic in Luke 5, 17-26 and similar stories about Peter and Paul in Acts (3, 1-10; 9, 32-35; 14, 8-11), of the revivification stories in Luke 7, 11-17 and Acts 9, 36-42; 20, 7-12, and of the summaries in Luke 4, 40-41; 6, 17-19 and in Acts 5, 1216. As an appendix he also briefly discusses Luke 22, 14-20 and the passages referring to common meals in Acts. With regard to the speeches, Lindemann does not pass by the clear similarities there are between Luke 4, 16-30 and Acts 2, 14-42 (Jesus and Peter both heavily rely on and quote from the OT), but he gives special attention to the differences (length of the discourse, setting, and above all the contrast between the "disastrous" result of Jesus and the success of Peter). Similarly, with regard to the healing stories, it is the differences that are especially to be noted, not only between the Gospel and Acts, but also in the three accounts in Acts (Peter performs the healing in 9, 32-35 as a means of converting the inhabitants of Lydda, whileas Paul's intervention serves to correct a misunderstanding from the side of his audience, and Peter's first miracle in 3,1-10 comes closer to the story in Lk 5, 17-26 with its christological accentuation). The stories about the raising of a dead person likewise serve different purposes: while the account in Acts 9, 36-42 can still be compared with the one in Luke 7, 11-17 for its emphasis on the power of the miracle worker (in both cases it is Jesus) but also adds as a new element that it brought many to believe in the Lord, the raising of Eutychos in Acts 20, 7-12 is performed in a Christian community and brings about relief and consolation.

The seminar papers gave rise to some very lively interventions which no doubt will be reflected in the published texts. An opportunity for discussing the main lectures was given in the evening session of the second day (the "Carrefour").

It is impossible to present in some detail the content of the 27 short papers that were read in parallel sessions on the morning of the second day. As can be expected a whole range of topics was addressed. Special attention was given to the prologues and the genre of Luke-Acts: L ALEXANDER (Sheffield), The theological and thematic unity of Luke-Acts: Reading Luke-Acts from back to front; D P MOESSNER (Dubuque, IA), The Lukan Prologues in the light of ancient narrative hermeneutics; S WALTON (Nottingham), Where 
does the beginning of Acts end?; E PLÜMACHER (Berlin), Cicero und Lukas. Bemerkungen zum Stil der Historischen Monographie; source criticism: T L BRODIE (Dublin), The unity of Proto-Luke; J M HARRINGTON (Minneapolis, MN), A consideration of the relationship between Luke 23, 6-16 and Acts 4, 25-27; Luke and Paul: G CARRAS (Berkeley), Contextualizing observant Jews in the story of Luke and Acts: Paul, Jesus and other Jews; J PICHLER (Graz), Das theologische Anliegen der Paulusrezeption im lukanis-chen Werk; G WASSERBERG (Kiel), Luke-Act als Paulusapologie; the geography of the Gospel and Acts: D BÉCHARD (New York), The theological significance of "Judaea" in Luke-Acts; G Geiger (Wien), Der Weg als roter Faden durch Luke - Apg; A PUIG I TẢrReCH (Barcelona), Les voyages à Jérusalem (Lc 9,51; Ac 19,21); B SchwANK (Beuron), "Das Wort der Herm geht aus von Jerusalem" (Jes 2, 3). Warum wurde das Apostelkonzil (Apg 15) nach vorn gezogen?; the relation with Judaism: P J TOMSON (Brussel), Gamaliel's counsel and the apologetic strategy of Luke-Acts; S VAN DEN EYNDE (Leuven), Children of the promise. On the $\delta 1 \alpha \theta \eta$ kn Promise to Abraham in Luke 1, 72 and Acts 3, 25; christology: C FoCANT (Louvain-la-Neuve), Du Fils de l'homme assis ( $\operatorname{Lc} 22,69)$ au Fils de l'homme debout (Ac 7, 56). Enjeux théologique et littéraire d'un change-ment sémantique; themes from Luke's theology and from his social world: M BACHMANN (Siegen), Die Stephanusepisode (Apg 6, 1-8,3) in ihrer Bedeutung für die lukanische Sicht des jerusalemischen Tempels; A DEL AGUA (Madrid), The Lucan narrative on the "evangelization of the Kingdom of God": A contribution to the unity of Luke-Acts; C HEIL (Bamberg), Johannes der Täufer im lukanischen Doppelwerk; G OEGEMA (Tübingen), Das Gebot der Nächstenliebe im lukanischen Doppelwerk; U SCHMID (Münster), Eklektische Textkonstitution als theologische Rekonstruktion - Gibt es das stellvertretende Sühneleiden Christi bei Lukas?; N TAYLOR (Zimbabwe), The Temple in Luke-Acts; F WILK (Jena), Apg 10, 111, 18 im Lichte der lukanischen Erzählung vom Wirken Jesu; B J KOET (Ut-recht), Why does Jesus not dream? Divine communication in Luke-Acts; V KOPERSKI (Miami, FL), Women and discipleship in Luke 10, 38-42 and Acts 6, 1-7; J MAGNE (Paris), La pauvreté dans Luc-Actes: théorie et pratique; K PAFFENROTH (Villanova PA), Famines in LukeActs.

During three days of intensive study and discussion several important issues regarding Luke's work were raised and many topics that are crucial to Christian theology were 
addressed. The papers that were read dealt with Luke's and the early Christians' views on God, Christ and the Spirit, with the message and the ministry of Jesus and of his disciples, and with the Church and the struggle of the early Christian communities with their Jewish roots. The Colloquium focused on specific areas of Luke's theology, examined particular passages from Luke and Acts and particular aspects of Luke's redaction, and asked methodological questions about the exegetical interpretation of his work. The participants were given many opportunities through the papers and the discussions to appreciate and admire the strength and the depth of Luke's theology and the elegance of his artistry as a writer and narrator. Above all, it has become evident ever more that these two impressive documents, Luke's Gospel and the Book of Acts, should be read and studied as the one great work by the same great author and theologian they were meant to be.

The Colloquium was sponsored by the National Fund for Scientific Research (FWO/FNRS, Brussels), the Katholieke Universiteit Leuven and the Université Catholique de Louvain. As usual, the lectures took place at the Maria-Theresia College and lodging was provided at the near-by Paus Adrianus VI College whose president, Prof L Leijssen, and his staff are thanked for their hospitality and kind support in preparing the meeting. The acts of the Colloquium will be published next year in the BETL series.

The topic of the 48th Colloquium Biblicum Lovaniense is "The Book of Genesis" (July 28-30, 1999; president A Wénin, Louvain-la-Neuve). The 49th session will be devoted to "The Sayings Source Q and the Historical Jesus" (July 25-27, 2000, president: A Lindemann, Bethel-Bielefeld).

* Permission for the reprint of this article has been given by the editor of Ephemerides Theologicae Lovanienses, Universiteitsbiliotheek Leuven, Belgium. 